\title{
Knowledge Levels of Vocational High School Students About Substance Addiction and Sexually Transmitted Diseases
}

\author{
Meslek Lisesi Öğrencilerinin Madde Bağımlılığı ve Cinsel Yolla \\ Bulaşan Hastalıklar hakkındaki Bilgi Düzeyleri
}

Gülay Börekçi (0000-0002-7879-7959), Derya Akdeniz Uysal* (0000-0002-7561-1821), Arzu Özel* (0000-0002-7200-4911), Döne Aksu* (0000-0003-2746-4895), Mualla Yılmaz** (0000-0003-2685-4306), Ayse Yüksel Sarı*** $(0000-0002-4351-7515)$,

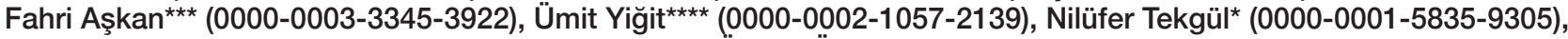
Adnan Batuhan Coşkun ${ }^{\star \star \star \star *}$ (0000-0002-5998-7474), Özcan Özdemir ${ }^{\star \star \star \star \star \star *}(0000-0002-7370-3271$, Tuba Güner Emül| ${ }^{\star \star \star \star \star \star \star \star}(0000-0002-6284-9419)$, Asiye Uzel $\left.\right|^{\star \star \star \star \star \star \star \star}(0000-0001-6315-6625)$,

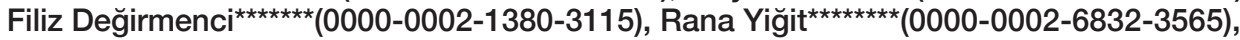
Bahar Taşdelen ${ }^{\star \star \star \star \star \star \star \star \star ~}(0000-0001-8146-4912)$

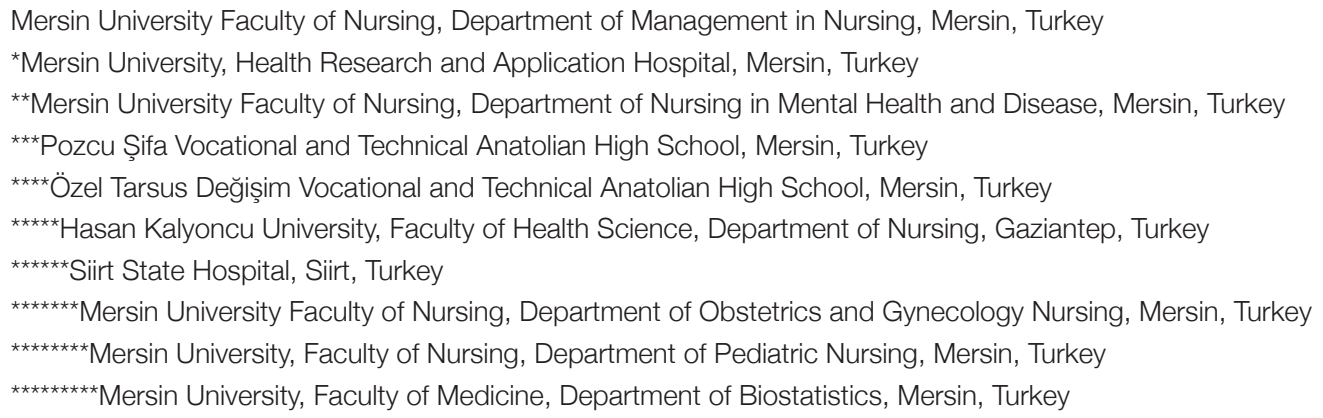

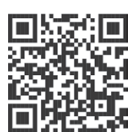

Keywords

Adolescence, substance addiction, sexual transmitted diseases

\section{Anahtar kelimeler \\ Adölesan, madde bağımlılı̆̆ı, cinsel yolla bulaşan hastalıklar}

Received/Geliş Tarihi : 07.12.2020

Accepted/Kabul Tarihi : 24.03.2021

\section{DOI:10.4274/jcp.2021.0027}

Address for Correspondence/Yazışma Adresi: Gülay Börekçi Prof. Dr., Mersin University Faculty of Nursing, Department of Management in Nursing, Mersin, Turkey E-mail: gulay_borekci@yahoo.com, gborekci@mersin.edu.tr

\begin{abstract}
Introduction: This study was carried out to determine the knowledge levels of vocational high school students about substance addiction and sexually transmitted diseases (STDs).

Materials and Methods: 20691 students from 22 vocational high schools were included in this study, and it was conducted with a total of 1929 students selected with stratified sampling. The data obtained in this study was collected using a questionnaire form.

Results: The mean age of the students was $16.58 \pm 1.17$, of which $54.1 \%$ were male, and $57.4 \%$ were high school 9-10th grade. It was determined that most of the students $(95.9 \%)$ lived with their families and $25.2 \%$ of them came with migration. $95.5 \%$ of the students stated that they had information about the health hazards of cigarettes, alcohol and other substances. While $60.9 \%$ of students stated knowing HIV/AIDS, $55.7 \%$ hepatitis B and $45.2 \%$ hepatitis C from STDs, $70.1 \%$ stated not knowing genital wart, $76.3 \%$ gonorrhea, $76.7 \%$ syphilis, $86.7 \%$ chlamydia, and $87.6 \%$ trichomonas. More than half of students stated knowing that STDs have symptoms like vaginal discharge odor $(56 \%)$, inguinal pain $(52.8 \%)$, itch $(52.1 \%)$, and wart and blister $(54.3 \%)$ in sexual organs. It was determined that more than half of the students do not know complications of STDs, and $41.5 \%$ of students stated that condom usage in every intercourse was necessary. $68.8 \%$ of the students did not receive any education about STD.

Conclusions: It was determined that the vocational high school students did not have enough information about STD and substance abuse and peer-based education were planned for the students.
\end{abstract}




\section{$\ddot{O} z$}

Giriş: Bu çalışma meslek lisesi öğrencilerinin madde bağımlılığı ve cinsel yolla bulaşan hastalıklar (CYBH) hakkındaki bilgi düzeylerini belirlemek amacıyla yapılmıştır.

Gereç ve Yöntem: Çalışmaya 22 meslek lisesinden 20691 öğrenci dahil edilmiş ve tabakalı örneklemle seçilen toplam 1929 öğrenci ile çalışma yürütülmüş̧ür. Çalışmada elde edilen veriler anket formu kullanılarak toplanmıştır.

Bulgular: Öğrencilerin yaş ortalaması 16,58 $\pm 1,17$ olup, bunların $\% 54,1^{\prime}$ i erkek, $\% 57,4$ 'ü lise $9-10$. sınıfta okumaktadır. Öğrencilerin çoğunun $(\% 95,9)$ aileleri ile yaşadığı ve \%25,2'sinin göç ile geldiği belirlenmiştir. Öğrencilerin \%95,5'i sigara, alkol ve diğer maddelerin sağlığa zararları hakkında bilgi sahibi olduğunu belirtmiştir. Öğrencilerin \%60,9'u CYBH'dan HIV/AIDS'i, \%55,7'si hepatit B ve \%45,2'si hepatit C'yi bildiğini belirtirken, \%70,1'i genital siğil, \%76,3'ü gonore, \%76,7'si sifiliz, \%86,7'si klamidya ve \%87,6'sı trikomonazı bilmediğini belirtmiştir. Öğrencilerin yarısından fazlası kötü kokulu akıntı (\%56), kasıklarda ağrı $(\% 52,8)$, kaşıntı $(\% 52,1)$ ve cinsel organlarda siğil ve uçuk $(\% 54,3)$ gibi CYBH'ın belirtileri olduğunu ifade etmiştir. Öğrencilerin yarıdan fazlasının CYBH'ın komplikasyonlarını bilmediği saptanmış ve CYBH'dan korunmada \%41,5'i her ilişkide kondom kullanılması gerektiğini belirtmiştir. Öğrencilerin \%68,8’i CYBH hakkında herhangi bir eğitim almamıştır.

Sonuç: Meslek lisesi öğrencilerinin cinsel yolla bulaşan hastalıklar ve madde bağımlılı̆̆ı konusunda yeterli bilgiye sahip olmadıkları saptanmış ve öğrenciler için akran temelli eğitimler planlanmıştır.

\section{Introduction}

The adolescent period is an important period in transition from childhood to adulthood when growth and development are quite fast, and besides, when cognitive and psychosocial development continues (1). Physiological and psychological changes in adolescents developing depending on their periodical characteristics may cause some important behavior changes in children of this age group that may cause problems on the psychosocial level. Children of particularly this age group seek new environments for themselves by emotionally moving away from family to be independent, and to gain a new status. This situation may bring many problems with adolescents' effort to prove themselves in new environments and with new experiences. Depending on this seeking, risky behaviors observed in the adolescent period may be ordered as drug usage, sexually transmitted diseases (STDs), accidents, suicides, violence and adolescent pregnancies $(2,3)$.

Substance addiction is a social problem with biological, emotional and social dimensions that can affect everyone, notably the young in our country as well, just like in the world $(2,3)$. According to the World Drug Report (2019), it is estimated that 271 million people, $5.5 \%$ of the global population between the ages of 15-64, had used drugs in the 2016 year. It is stated that most drug-related deaths (585.000 deaths) result from hepatitis $\mathrm{C}$ and opioid use disorder (2). According to the Turkish Drug Report 2019, the rate of those using drugs at least once in their lives between ages 15-24 is the highest (35.4\%) (3). Spreading drug use with immigrations, rapid urbanization, economic imbalances, socio-cultural changes and entertainment culture create serious problems in our country. Besides, because of Turkey's geographical location, its being in a strategic points in the world in the substances addiction trafficking increases the danger more. It is reported that drug usage is higher in port or close-to-port cities geographically. Being a port city and allowing high immigration causes Mersin city to be one of the important centers in drug trafficking (4). Starting drug usage at a young age causes the longer use of this substance, and long-term drug usage causes serious health problems in the future lives of individuals.

Sexually transmitted diseases are the most common and dangerous among infectious diseases. The most frequent STDs are gonorrhea, syphilis, chlamydia, genital herpes, hepatitis $\mathrm{B}$, human papilloma virus (HPV), and human immmunodeficiency virus/ acquired immune deficiency syndrome (HIV/AIDS). According to the World Health Organization (WHO) for 2016, more than one million people are infected by STDs daily. Each year, 376 million new infections occur with one of the four STDs (chlamydia, gonorrhea, syphilis, and trichomoniasis); and besides, 417 million people have herpes simplex virus (HSV), and more than 290 million women have human papillomavirus (HPV) infection (5).

According to WHO HIV/AIDS Report, 37.9 million people were predicted to have HIV/AIDS at the end of 2018, and of those, 36.2 million are adults, and 1.7 million are children aged under 15. People newly infected with HIV are 1.7 million in 2018, and it is stated that 770.000 people died from AIDS-related 
diseases (6). While newly infected HIV/AIDS cases decrease throughout the world, the number continues to increase in our country $(6,7)$. In our country, the young population constitutes an important part of society. According to the data of the Ministry of Health, HIV positivity has been increasing in adolescents and it is seen that the newly infected ones are young (7). Unfortunately, that the young do not have sufficient information about STD at that period, that they cannot get information from the correct sources, and their being misinformed cause difficulties in fight against these diseases. It was identified in studies conducted in our country that students have insufficient information about STDs, and that they would like to get information about STDs $(8,9,10)$.

Mersin is a cosmopolitan tourism city where migrations are high and exposed to socio-cultural changes. In our country, vocational high school students settle in schools with the lowest points, and their education includes mostly vocational knowledge. These students, who have more free time, are at risk for substance use and sexually transmitted diseases. In our city, representing a great portion of schoolage youngsters in high school, vocational high school students make up an important group that may be exposed to threats like drug usage and STDs. According to our research, there is no comprehensive study that determines the knowledge level of vocational high school students about substance addiction and STDs in our country. The aim of this study is to determine the knowledge levels of vocational high school students about substance addiction and STDs, and to determine their educational needs.

\section{Materials and Methods}

This descriptive study was conducted to determine the knowledge levels of vocational high school students about substance addiction and sexually transmitted diseases. A total of 20.691 vocational high school students from 22 vocational high schools having education in $9^{\text {th }}-12^{\text {th }}$ grade in Mersin Province were included in this study and it was conducted with a total of 1929 students selected with stratified sampling.

In data collection, questionnaire form related to socio-demographic characteristics, substance addiction and sexually transmitted diseases information form prepared by researchers in accordance with literature were used $(4,8-28)$. Socio- demographic information form includes questions about the students' age, gender, school, department, and class. In the sexually transmitted diseases information form, there are questions about sexually transmitted diseases, the modes of transmission of the diseases, symptoms and consequences, treatment and prevention. Substance addiction questionnaire consists of questions containing students' information about substances harmful to health. There are 51 questions in the survey together with their subgroups. After getting necessary permissions (governorship approval, ministry of education permission slip, and ethic committee approval), questionnaire was applied to 1929 students to determine information levels of students. Students were orally informed about the study, their consent was taken, and only the voluntary ones were included in the study. After the knowledge levels of students about sexually transmitted diseases and substance addiction were determined, peer-based education to students about sexually transmitted diseases and substance addiction was planned and educational materials (power point presentation, brochure) have been prepared to increase of knowledge level of students about these items.

\section{Statistical Analysis}

The obtained data were analyzed using STATISTICA 13.0 program. The data were expressed as number (n) and frequency (\%), and the relationships between categorical variables were determined using the chi-square test $\left(\chi^{2}\right)$. Pairwise grade comparisons were done using two proportions $\mathrm{z}$ test. $\mathrm{p}<0.05$ was evaluated as the level of statistical significance.

\section{Ethical issues}

This study was conducted in accordance with the Helsinki Declaration Principles, it was approved by the clinical investigations ethics committee from Mersin University (Mersin University Clinical Research Ethics Committee, No: 2015/300) and informed consent was obtained from all the study participants.

\section{Results}

The mean age of students was $16.58 \pm 1.17$, and $54.1 \%$ of them were male. It was identified that $57.4 \%$ of students were high school 9th-10th grade, 
that $95.9 \%$ of them were living with their families, that $25.2 \%$ came by immigration, and that the mean monthly income of their families was low (Table 1).

Table 1. Sociodemographic characteristics of students $(\mathrm{n}=1929)$

\begin{tabular}{|c|c|c|c|}
\hline \multicolumn{4}{|l|}{ Characteristics } \\
\hline & & $\mathrm{n}$ & $\%$ \\
\hline \multirow[t]{3}{*}{ Gender } & Male & 1043 & 54.1 \\
\hline & Female & 886 & 45.9 \\
\hline & $9^{\text {th }}$ grade & 573 & 29.7 \\
\hline \multirow[t]{3}{*}{ Grade of school } & $10^{\text {th }}$ grade & 535 & 27.7 \\
\hline & $11^{\text {th }}$ grade & 436 & 22.6 \\
\hline & $12^{\text {th }}$ grade & 385 & 20.0 \\
\hline \multirow{4}{*}{$\begin{array}{l}\text { Longest place } \\
\text { resided }\end{array}$} & City & 1277 & 66.2 \\
\hline & District & 444 & 23.0 \\
\hline & Village & 195 & 10.1 \\
\hline & Abroad & 13 & 0.7 \\
\hline \multirow{5}{*}{$\begin{array}{l}\text { Immigration } \\
\text { status }\end{array}$} & Yes & 487 & 25.2 \\
\hline & No & 1442 & 74.8 \\
\hline & With my family & 1849 & 95.9 \\
\hline & With my relatives & 34 & 1.8 \\
\hline & In a state dormitory & 24 & 1.2 \\
\hline \multirow[t]{6}{*}{ Living place } & With my friends & 5 & 0.2 \\
\hline & In an orphanage & 4 & 0.2 \\
\hline & Alone & 3 & 0.2 \\
\hline & In the street & 8 & 0.4 \\
\hline & Other & 2 & 0.1 \\
\hline & Illiterate & 311 & 16.1 \\
\hline \multirow{7}{*}{$\begin{array}{l}\text { Mother's } \\
\text { education status }\end{array}$} & Literate & 104 & 5.4 \\
\hline & Primary School Graduate & 760 & 39.4 \\
\hline & Secondary School Graduate & 407 & 21.1 \\
\hline & High School Graduate & 288 & 14.9 \\
\hline & University Graduate & 59 & 3.1 \\
\hline & Illiterate & 78 & 4.0 \\
\hline & Literate & 102 & 5.3 \\
\hline \multirow{4}{*}{$\begin{array}{l}\text { Father's } \\
\text { education status }\end{array}$} & Primary School Graduate & 682 & 35.4 \\
\hline & Secondary School Graduate & 546 & 28.3 \\
\hline & High School Graduate & 381 & 19.8 \\
\hline & University Graduate & 140 & 7.2 \\
\hline \multirow{6}{*}{$\begin{array}{l}\text { Mother's } \\
\text { occupation }\end{array}$} & Housewife & 1598 & 82.8 \\
\hline & Worker & 155 & 8.0 \\
\hline & Self-Employed & 99 & 5.2 \\
\hline & Officer & 48 & 2.5 \\
\hline & Retired & 18 & 0.9 \\
\hline & Farmer & 11 & 0.6 \\
\hline \multirow{6}{*}{$\begin{array}{l}\text { Father's } \\
\text { occupation }\end{array}$} & Self-Employed & 738 & 38.3 \\
\hline & Worker & 721 & 37.4 \\
\hline & Retired & 177 & 9.2 \\
\hline & Officer & 166 & 8.6 \\
\hline & Farmer & 96 & 5.0 \\
\hline & Tradesman & 31 & 1.5 \\
\hline
\end{tabular}

When the knowledge level of students about STDs was examined, it was identified that $60.9 \%$ of them knew HIV/AIDS, $55.7 \%$ hepatitis B, $45.2 \%$ hepatitis $\mathrm{C}$ as sexually transmitted diseases, but that $76.7 \%$ of them did not know syphilis, $76.3 \%$ gonorrhea, $71.4 \%$ genital herpes, $87.6 \%$ trichomonas and $86.7 \%$ chlamydia. It was defined that while $82.9 \%$ of students knew sexual intercourse, $66.1 \%$ certain commonly used tools (injector, razor, manicure set, etc.), $51.7 \%$ blood and organ transfusion as sources of infection, the awareness rate of students about other ways of infection were low. It was identified that the rates of the students knowing other symptoms and results of STDs were relatively lower (Table 2).

Knowledge level of students about treatment and vaccination of STDs was given in Table 3. Most of the students stated not having information about vaccination and treatment of STDs.

The difference between the knowledge level of the students about substance addiction and gender characteristics was examined, and it was found statistically significance. When compared to male students, female students knew more that substances such as marijuana, opium, ecstasy and captagon makes addiction $(\mathrm{p}=0.001, \mathrm{p}=0.001)$ (Table 4$)$.

The difference between the knowledge level of students about STDs and gender characteristic was examined, and a statistically significance relationship between them was identified. The number of male students stating of knowing STDs was identified more than the number of female students such as HIV/ AIDS, syphilis, chlamydial infection and gonorrhoea $(\mathrm{p}=0.0001, \mathrm{p}=0.005, \mathrm{p}=0.006, \mathrm{p}=0.007)$ (Table 5). The relationship between the knowledge level of students about STDs and grade difference was statistically significance. It was determined that the $12^{\text {th }}$ grade students have more information than $9^{\text {th }}$ grade students about STDs, and that their information increases as the grade level increases $(\mathrm{p}=0.001, \mathrm{p}=0.0001)$ (Table 6).

When the sources of information of students about STDs and substance addiction were examined, it was determined that more than half of students did not have any education. The other students get the most information about substance addiction and STDs from school, family, media and internet. The rate of getting information of the students from healthcare personnel was quite low. However, it was determined that students obtained more information about substance 
addiction from these information sources and could not benefit from these sources on STDs. Moreover, students stated that they would like to have education about STDs from healthcare personnel.

\section{Discussion}

The adolescence period is a period when risky health behavior is frequently observed, and so which is under risk in terms of reproductive health. That the topics related to reproductive health are taboo in our country prevents the young people from reaching the correct information, from creating awareness, and from prevention from possible risks. As a result of this, lack of information increases risky behaviors concomitantly, and cause situations like drug usage, sexual intercourse at early age, unintended pregnancies, and catching STDs $(11,12)$.

In this study, it was determined that a great majority of students have knowledge about health hazards of addictive substances. In other studies conducted in our

Table 2. Knowledge level of students about transmission way, symptoms and prevention of STDs

\begin{tabular}{|c|c|c|c|c|c|c|}
\hline & \multicolumn{2}{|l|}{ Yes } & \multicolumn{2}{|l|}{ No } & \multicolumn{2}{|c|}{ Does not know } \\
\hline & $\mathrm{n}$ & $\%$ & $\mathrm{n}$ & $\%$ & $\mathrm{n}$ & $\%$ \\
\hline \multicolumn{7}{|l|}{ Answers to STDs'transmission ways } \\
\hline With sexual intercourse & 1600 & 82.9 & 60 & 3.2 & 269 & 13.9 \\
\hline With commonly used tools (injector, razor, manicure set, etc.) & 1276 & 66.1 & 202 & 10.5 & 451 & 23.4 \\
\hline With HIV/AIDS, hepatitis $\mathrm{B} / \mathrm{C}$, blood and organ transplant of the patient & 998 & 51.8 & 161 & 8.3 & 770 & 39.9 \\
\hline During pregnancy and breastfeeding from mother to baby & 836 & 43.4 & 365 & 18.9 & 728 & 37.7 \\
\hline With respiration & 768 & 39.8 & 534 & 27.7 & 627 & 32.5 \\
\hline With HIV/AIDS, hepatitis B/C, tattoo/piercing & 702 & 36.4 & 255 & 13.2 & 972 & 50.4 \\
\hline With using the same toilet/bathroom & 698 & 36.2 & 588 & 30.5 & 643 & 33.3 \\
\hline With mosquito/bug bite & 547 & 28.4 & 641 & 33.2 & 741 & 38.4 \\
\hline With kissing from cheek to cheek & 442 & 22.9 & 947 & 49.1 & 540 & 28.0 \\
\hline \multicolumn{7}{|l|}{ Answers to STDs' symptoms and results } \\
\hline Vaginal discharge odor in sexual organs may occur & 1081 & 56.0 & 61 & 3.2 & 787 & 40.8 \\
\hline Wound, wart, herpes may occur in sexual organs & 1048 & 54.3 & 120 & 6.2 & 761 & 39.5 \\
\hline Pain may occur in groins & 1018 & 52.8 & 115 & 6.0 & 796 & 41.2 \\
\hline Itch may occur on sexual organs & 1005 & 52.1 & 113 & 5.9 & 811 & 42.0 \\
\hline Pain/Bleeding may occur during sexual intercourse & 999 & 51.8 & 121 & 6.3 & 809 & 41.9 \\
\hline May cause death & 953 & 49.4 & 128 & 6.6 & 848 & 44.0 \\
\hline May cause illness in newborn babies & 931 & 48.3 & 121 & 6.2 & 877 & 45.5 \\
\hline Cancer may occur on sexual organ & 939 & 48.7 & 125 & 6.5 & 865 & 44.8 \\
\hline Painful and frequent urination may occur & 926 & 48.0 & 129 & 6.7 & 874 & 45.3 \\
\hline Swelling and alveolus in groins may occur & 865 & 44.8 & 135 & 7.0 & 929 & 48.2 \\
\hline May cause premature birth/aborts & 799 & 41.4 & 139 & 7.2 & 991 & 51.4 \\
\hline May cause infertility & 765 & 39.7 & 161 & 8.3 & 1003 & 52.0 \\
\hline May cause impotence & 580 & 30.1 & 194 & 10.0 & 1155 & 59.9 \\
\hline \multicolumn{7}{|l|}{ Answers to prevention from STDs } \\
\hline Avoiding drug usage & 1315 & 68.2 & 166 & 8.6 & 448 & 23.2 \\
\hline Avoiding common usage of tools like razor, injector, nail clipper & 1253 & 65.0 & 150 & 7.8 & 526 & 27.2 \\
\hline Avoiding intercourse with risky people (prostitutes, homosexuals) & 1206 & 62.5 & 124 & 6.4 & 599 & 31.1 \\
\hline Maintaining monogamy in sexual intercourse & 1049 & 54.4 & 245 & 12.7 & 635 & 32.9 \\
\hline Using condom in every intercourse & 801 & 41.5 & 192 & 10.0 & 936 & 48.5 \\
\hline
\end{tabular}


Table 3. Knowledge level of students about treatment and vaccination of STDs

\begin{tabular}{|c|c|c|}
\hline Answers related to treatment of STDs & $\mathrm{n}$ & $\%$ \\
\hline \multicolumn{3}{|l|}{ Treatment of HIV/AIDS } \\
\hline Existent & 527 & 27.3 \\
\hline Non-existent & 367 & 19.0 \\
\hline Does not know & 1035 & 53.7 \\
\hline \multicolumn{3}{|l|}{ Treatment of Hepatitis B } \\
\hline Existent & 699 & 36.2 \\
\hline Non-existent & 140 & 7.3 \\
\hline Does not know & 1090 & 56.5 \\
\hline \multicolumn{3}{|l|}{ Treatment of Hepatitis C } \\
\hline Existent & 614 & 31.8 \\
\hline Non-existent & 113 & 5.9 \\
\hline Does not know & 1202 & 62.3 \\
\hline \multicolumn{3}{|l|}{ Treatment of Syphilis } \\
\hline Existent & 299 & 15.5 \\
\hline Non-existent & 121 & 6.3 \\
\hline Does not know & 1509 & 78.2 \\
\hline \multicolumn{3}{|l|}{ Treatment of Gonorrhea } \\
\hline Existent & 438 & 22.7 \\
\hline Non-existent & 91 & 4.7 \\
\hline Does not know & 1400 & 72.6 \\
\hline \multicolumn{3}{|l|}{ Treatment of Genital wart (HPV) } \\
\hline Existent & 453 & 23.5 \\
\hline Non-existent & 108 & 5.6 \\
\hline Does not know & 1368 & 70.9 \\
\hline \multicolumn{3}{|l|}{ Treatment of Genital herpes } \\
\hline Existent & 491 & 25.5 \\
\hline Non-existent & 79 & 4.1 \\
\hline Does not know & 1359 & 70.4 \\
\hline \multicolumn{3}{|l|}{ Treatment of Trichomonas } \\
\hline Existent & 233 & 12.1 \\
\hline Non-existent & 79 & 4.1 \\
\hline Does not know & 1617 & 83.8 \\
\hline \multicolumn{3}{|l|}{ Treatment of Fungus } \\
\hline Existent & 916 & 47.5 \\
\hline Non-existent & 72 & 3.7 \\
\hline Does not know & 941 & 48.8 \\
\hline \multicolumn{3}{|l|}{ Treatment of Chlamydia } \\
\hline Existent & 214 & 11.1 \\
\hline Non-existent & 116 & 6.0 \\
\hline Does not know & 1599 & 82.9 \\
\hline
\end{tabular}

Table 3. Continued

Answers related to treatment of STDs

$\mathrm{n}$

$\%$

Answers related to vaccination of STDs

Vaccination of HIV/AIDS

Existent

$347 \quad 18.0$

Non-existent

$248 \quad 12.8$

Does not know

$1334 \quad 69.2$

Vaccination of Hepatitis B

Existent

$696 \quad 36.1$

Non-existent

$68 \quad 3.5$

Does not know

$1165 \quad 60.4$

Vaccination of Hepatitis C

Existent

$569 \quad 29.5$

Non-existent

$83 \quad 4.3$

Does not know

$1277 \quad 66.2$

Vaccination of Syphilis

Existent

$179 \quad 9.3$

Non-existent

$107 \quad 5.5$

Does not know

$1643 \quad 85.2$

Vaccination of Gonorrhea

$211 \quad 10.9$

Existent

$136 \quad 7.1$

Non-existent

$1582 \quad 82.0$

Vaccination of Genital wart (HPV)

Existent

$194 \quad 10.1$

Non-existent

$127 \quad 6.5$

Does not know

$1608 \quad 83.4$

Vaccination of Genital herpes

Existent

$189 \quad 9.8$

Non-existent

$148 \quad 7.7$

Does not know

$1592 \quad 82.5$

Vaccination of Trichomonas

Existent

$122 \quad 6.3$

Non-existent

$\begin{array}{ll}90 & 4.7\end{array}$

Does not know

$1717 \quad 89.0$

Vaccination of Fungus

Existent

$322 \quad 16.7$

Non-existent

$210 \quad 10.9$

Does not know

$1397 \quad 72.4$

Vaccination of Chlamydia

Existent

$132 \quad 6.8$

Non-existent

$88 \quad 4.6$

Does not know 
country, the majority of the students stated that they had knowledge on substance addiction, were informed and gained information on addictive substances from school $(13,14)$. In studies performed in other countries, a study by Siddiqui and Salim on substance addiction in young Saudi Students, it was determined that $84.2 \%$ of students have sufficient information level on the topic (15). In the study of Gotsang et al. with students at adolescence period in Botswana, it was determined that they are informed about addictive substances and their abuse, and that had information from television, newspaper and from friends (16). In a study conducted

Table 4. The difference between the knowledge level of students about substance addiction and gender characteristics

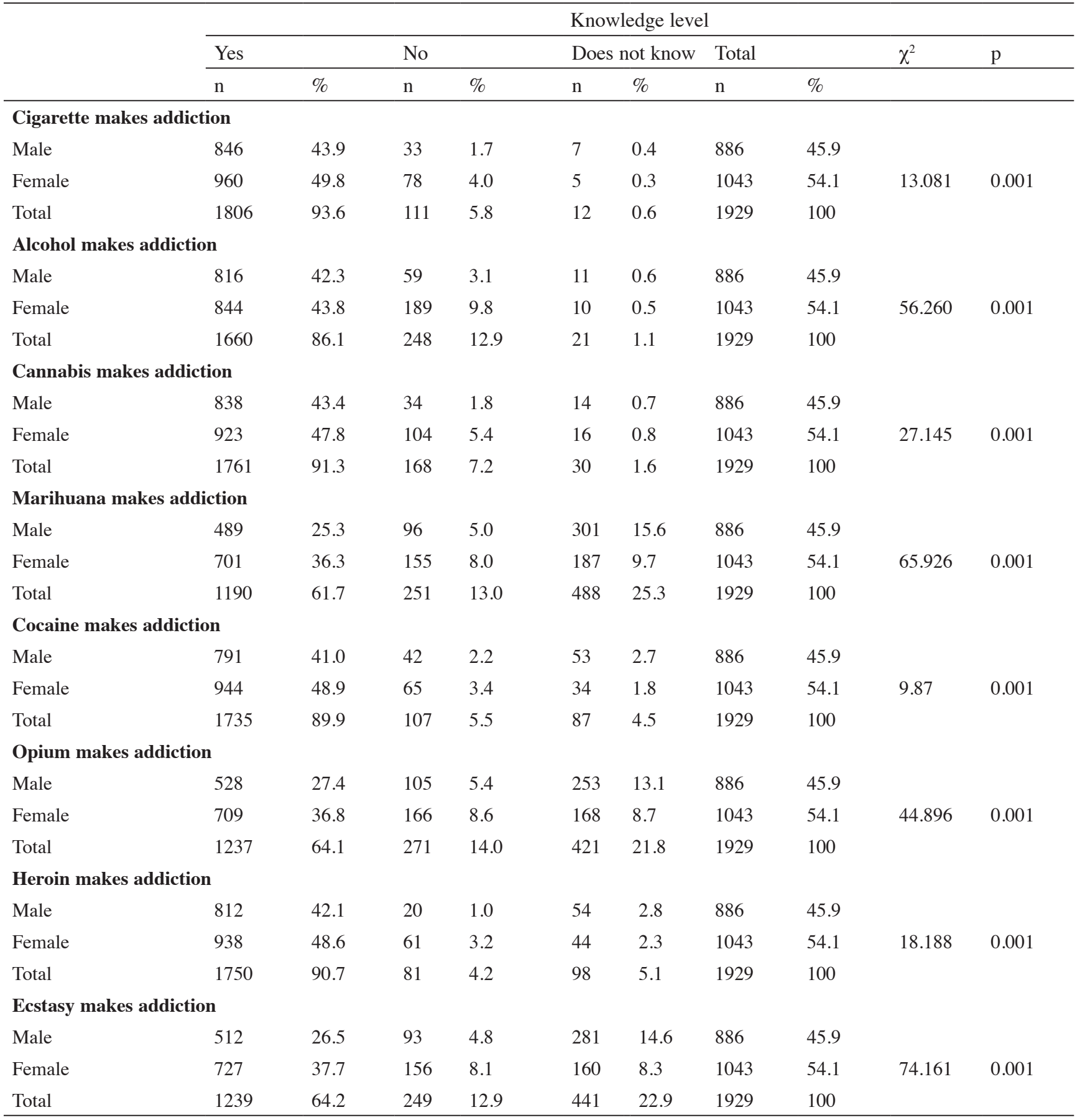


in Malesia, information levels of students on substance addiction were found as $82 \%$ (17). In another study conducted in India about the same topic, it was reported that of high school students, $90.6 \%$ have mediumlevel, and $7.5 \%$ have a good level of information (18). In the study of Nwosu and Ezejindu in Nigeria, the information levels of students on substance addiction were determined as insufficient (19). Although studies done in other countries differ from each other, studies conducted in our country show that the young people are well-informed about substance addiction. The reason for their high level of knowledge of students on

Table 5. The difference between the knowledge level of students about STDs and gender characteristics

\begin{tabular}{lllllll}
\multicolumn{7}{c}{ Knowledge level } \\
\hline Knows & \multicolumn{2}{l}{ Does'nt know } & Total & $\chi^{2}$ & $\mathrm{p}$ \\
\hline $\mathrm{n}$ & $\%$ & $\mathrm{n}$ & $\%$ & & & \\
\hline
\end{tabular}

\section{HIV/AIDS}

Male

Female

Total

\section{Hepatitis B}

Male

Female

Total

\section{Hepatitis C}

Male

Female

Total

Syphilis

Male

Female

Total

Gonorrhoea

Male

Female

Total

Genital herpes

Male

Female

Total

Chlamidial infection

Male

Female

Total

Fungal infection

Male

Female

Total

$\begin{array}{lll}591 & 30.6 & 295 \\ 583 & 30.2 & 460 \\ 1174 & 60.9 & 755\end{array}$

1174

60.9

755

563

511

1074

29.2

323

$26.5 \quad 532$

55.7

855

$431 \quad 22.3 \quad 455$

441

22.9

455

872

45.2

232

217

12.0

11.2

23.3

1057

449

235

222

457

$12.2 \quad 651$

$11.5 \quad 821$

23.7

1472

310

266

16.1

13.8

29.9

97

159

256

$$
5.0
$$

8.2

13.3

\section{9}

884

1673

542

501

\section{1}

26.0

1043

\section{4}

542

54.1
886
15.3

23.8

39.1

16.7

27.6

44.3

23.6

31.2

54.8

33.3

42.8

76.7

33.7

42.6

76.3

29.9

40.3

70.1

40.9

45.8

86.7

886

1043

1929

886

1043

1929

886

1043

1929

886

1043

1929

886

1043

1929

886

1043

1929

886

1043

1929

17.8

28.1

886

1043

45.9

1929
45.9

54.1

23.492

0.0001

100

45.9

54.1

41.101

0.0001

100

45.9

54.1

7.832

0.005

100

45.9

54.1

7.764

0.005

100

45.9

54.1

7.273

0.007

100

45.9

54.1

20.580

0.0001

100

45.9

54.1

7.683

0.006

100

45.9

54.1

33.302

0.0001

100 
Table 6. The difference the knowledge level of students about STDs and grade difference

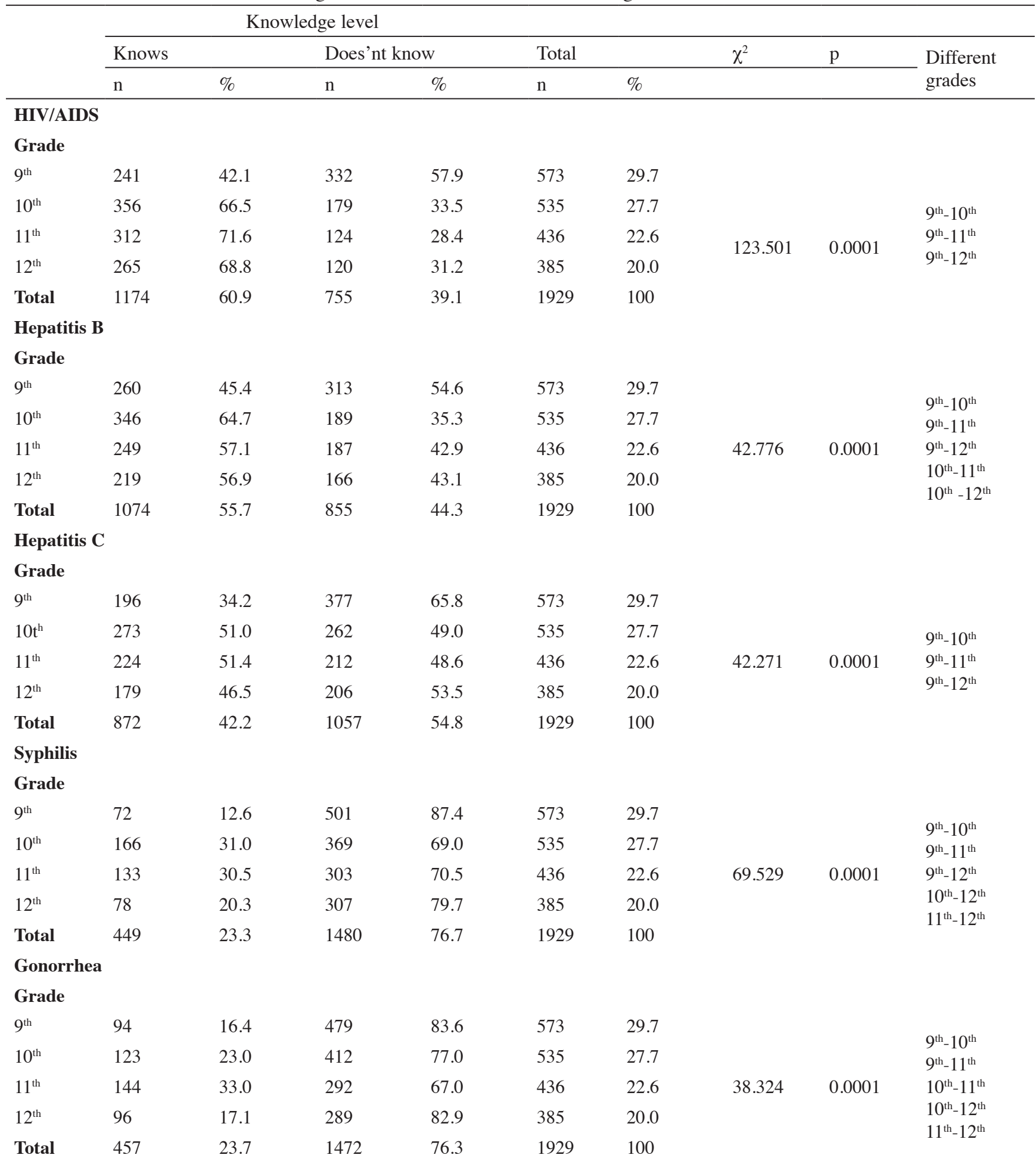




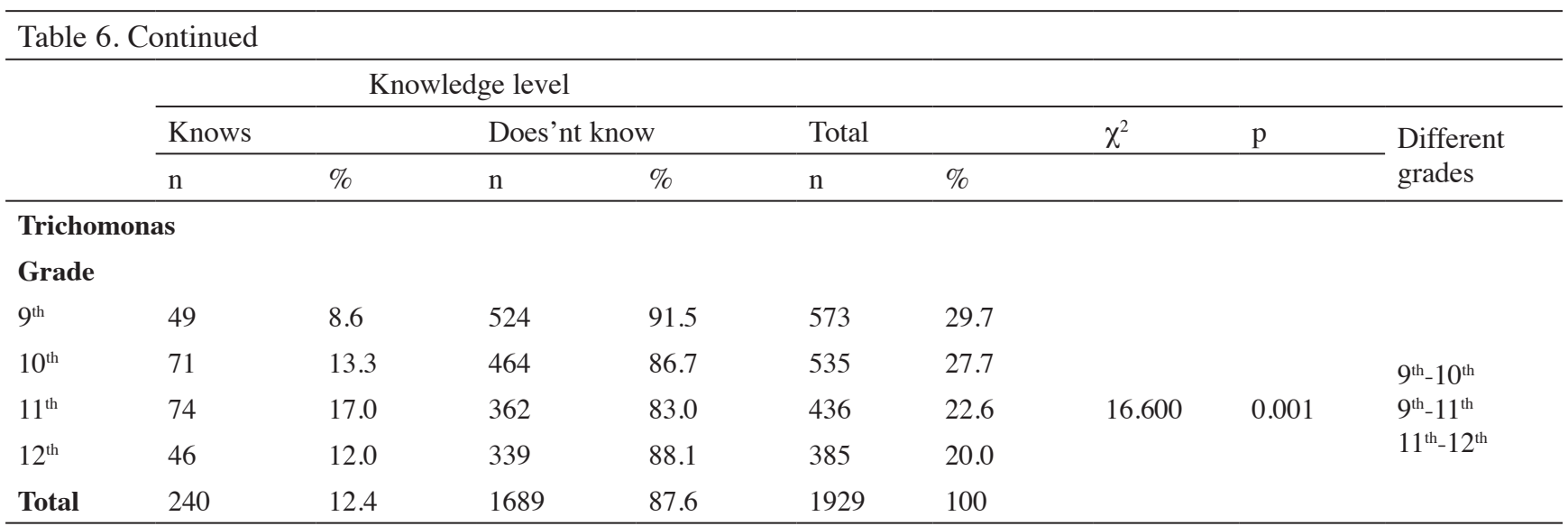

this topic in our country shows that educations (such as media and public education) to the fight against substance abuse are important. However, drug usage status of students in this study is unknown.

In our study, when information levels of students about STDs were examined, it was seen that the most well-known sexually transmitted disease was HIV/ AIDS. Similar to our study, in the study of Demir and Şahin, the best-known disease was HIV/AIDS, but this ratio was lower than our study (9). In another study of Elkin, the most known STDs among university students were, respectively, AIDS, syphilis, hepatitis B, hepatitis C, and fungus (20). In the study of Amu and Adegun, it was determined that best-known disease was AIDS and gonorrhea, respectively (21). In a study conducted with female students by Nwatu et al., it was found that the most known diseases were gonorrhea, AIDS and syphilis, respectively, and the least known disease was genital herpes (22). In our study, it was determined that, from STDs, hepatitis B and hepatitis $\mathrm{C}$ are less known by students, whereas students do not know other STDs such as syphilis, gonorrhea, genital herpes, trichomonas, and chlamydia. In other studies, although HIV/AIDS is the most known disease, it can be seen that other STDs are less known (21-25). As AIDS disease is frequently shown in media, and a current and important problem, its status of being known is higher compared to other diseases. However, these studies showed that this rate is still not in the desired level $(20,24,25)$.

Although most of the students stated that sexually transmitted diseases were transmitted through sexual intercourse, it was determined that almost half of the students had wrong information (commonly used toilet, respiration, etc.) in our study. In Genz et al.'s study, almost all the students knew that STDs is transmitted with sexual intercourse (23). In Yazganoğlu et al.'s study, students stated that STDs can be transmitted through sexual intercourse, through blood, and through anal intercourse (25). In the same study, students stated that HIV can be transmitted through handshake or mosquito bite. In another study, students stated that STDs can be infected through unprotected sexual intercourse, through injector sharing, through blood and blood products, and from mother to baby. In the same study, students stated that STDs can also be transmitted with cough/sneeze, and with common toilet usage (21). In another study, more than half of the students stated that AIDS can be infected with common usage of plate, glass, bathroom and toilet, and with contact like handshake, hug (20). When studies are examined, it can be seen that the young people have wrong information about ways of infection, and that they are insufficient about protecting themselves.

In our study, more than half of the students stated that vaginal discharge odor, wound, wart, herpes, itch may be the symptom or result of STD. In some studies, more than half of the students stated that wound in exterior genital organs, itch, inguinal pain, menstrual irregularity, difficulty and burning in urination, discharge in vagina and penis as symptoms of STDs $(9,26,27)$. In another study, more than half of the students stated of knowing genital discharge, genital ulcer, urinary burning as symptoms (28). In Amu and Adegun's study, students stated that weight loss and rash on body may occur (21). It was seen that students needed more information about the symptoms or consequences of STD.

According to our study results, more than half of the students stated that STDs may cause premature 
births and abortions, cancer in sexual organs and death, and disease in newborn babies. In Çalışkan et al.'s study, if STDs are untreated, students stated that they may cause infertility, and that visual disability in newborn baby (29). In Bakır and Kizılkaya Beji's study, university students stated that visual disability in newborn baby may occur as a result of STDs (30). In other studies, done as parallel to our study results, it can be seen that many students do not have sufficient information about the results of STDs.

In our study, to the questions related to protection from STDs, students answered as avoiding drug usage, as maintaining monogamy in sexual intercourse, as using condom in every intercourse. In Nwatu et al.'s study, students stated that they can be protected from STDs by avoiding unprotected sexual intercourse, by having intercourse with one partner, by avoiding injector sharing, by avoiding careless use of blood and blood products (22). Besides these answers, it was also determined that there are wrong beliefs about ways of protection, like not sharing the same chair with infected people, not shaking hands, not sharing the same toilet, not using kitchen tools. In Yazganoğlu et al.'s study with university students, the best known three protection methods are stated as avoiding contact with prostitutes (sex workers) (82.6\%), using condom during sexual intercourse (77.6\%), and limiting sexual partner number (monogamy) (66.9\%) (25). In Çalışkan et al.'s study, students stated that condom usage can be effective in STDs (29). In Demir and Şahin's study, students answered as not having intercourse with risky people, using contraceptive pill, not having sexual intercourse with anyone to protect from these diseases. The study results showed that although students have correct information to protect from STDs, they also have wrong information (9).

In our study, it was determined that gender, grade and family education levels of students affected their knowledge levels. We found that female students know STDs more than male students. Similar to the results of our study, in Biri et al.'s study, the rate of female students knowing STDs was found more compared to male students (24). In Bakır and Kizllkaya Beji with Çalışkan et al.'s studies, male students answered more questions correctly compared to female students $(29,30)$. These differences may be resulted from the variety of cultural characteristics and social pressures in our country. In our study, it was detected that the information levels of students about STDs increase as their grade levels increase. In Çaltık Yilmaz and Başkan's study on information levels about AIDS with primary and high school students, in terms of answering questions correctly, significance difference was determined between primary and high school students (26). Furthermore, in our study, it was found that as parents' education levels increase, students' information levels about STDs also increase. Having the same results in the studies of Çalışkan et al. (29) and Malki (31) showed the importance of education taken from the family. Similar to the results of our study, the studies showed that some sociodemographic characteristics such as gender, education level of parents and grade level of school, etc. have increased of the knowledge level of students $(24,26,29)$. In our study, it was determined that more than half of students did not have any education on substance addiction and STDs. Students get the most information about substance addiction and STDs from school, family, media and internet. The rate of getting information of the students from healthcare personnel was quite low. Similar to our study, it was determined in the other studies that students have get the information on these matter from family, school, media and internet $(21,23,24)$. In the some studies conducted, the rate of getting information from a health institution was detected as quite low $(9,23,24)$. The results of the studies showed that young people turned to information sources such as internet and media except the family and school. Whereas, in our study, many of students stated that they would like to have education about STDs and substance addiction from healthcare personnel. As resources such as internet give limited information, applying to a healthcare institution to reach correct information about correct and quick diagnosis, treatment and protection are of great importance.

\section{Conclusion}

In our study, it was determined that students do not have sufficient information related to substance addiction and STDs, and that they have education needs on this topic. In our country, studies related to the level of knowledge on this subject differ, as well as similar results in other countries. In a study conducted by Tavoosi et al. with high school students regarding AIDS in Iran, only a few students answered all the knowledge questions 
correctly, and there were many misconceptions about the routes of transmission (32). In the another study, Andrew et al. evaluated knowledge level about HIV/ AIDS among African-American undergraduate students and $96.5 \%$ of students had good knowledge about HIV/AIDS, however, some participants had misconceptions about the transmission modes of HIV infection (33). In general, the studies showed that levels of awareness and knowledge of young population about STDs and substance addictive in various country are low or moderate levels $(19,23,28,32,34,35,36)$. In our country, information studies about substance addiction and STDs are done at school sometimes as conference, panel, but as these educations do not have continuation, they do not reach to satisfactory levels. Although there are centers in our country treating drug addicts, as they are few in number, information studies towards protection cannot be done at a sufficient level by these centers. There is not a single center that can give consultation about STDs, and although health institutions take on this task, it is difficult to reach all individuals in society and all the young people at schools. Setting up units in family health centers to give consultation on substance addiction and STDs, making peer-based education at schools in company with school counsellors or experts can be useful. In accordance with the results we obtained from this study, making peer-based education was planned for all the students at schools within the scope of this study to create awareness about and inform on drug usage and STDs. New methodological approaches may be needed to attract young people.

Acknowledgement: We would like to thank all the students and teachers in Vocational High School in Mersin, Turkey.

\section{Ethics}

Ethics Committee Approval: This study was conducted in accordance with the Helsinki Declaration Principles, it was approved by the clinical investigations ethics committee from Mersin University (Mersin University Clinical Research Ethics Committee, no: 2015/300).

Conflict of Interest: No conflict of interest was declared by the authors.

Financial Disclosure: The authors declared that this study received no financial support.

\section{References}

1. Yiğit R. [Growth and development in childhood]. 1. bask1; Ofset Yayıncıllk, Ankara, 2012.p. 177.

2. World Drug Report. United Nations Office on Drugs and Crime (UNODC) Executive Summary Conclusions and Policy Implications, 2019.

3. Turkish Drug Report. Republic of Turkey Ministry of Interior Turkish National Police Counter Narcotics Department. Ankara; 2019. http://www.narkotik.pol.tr/kurumlar/narkotik. pol.tr/TUB\%C4\%B0M/Ulusal\%20Yay\%C4\%B 1nlar/2019TURKISH-DRUG-REPORT_30122019.pdf.

4. Börekçi G, Uzel A. [The level of knowledge about HIV/AIDS of drug users in Mersin city]. Erciyes Med J 2013;35:56-62.

5. WHO: Report on global sexually transmitted infection surveillance. Geneva: World Health; 2018. p.1-74.

6. UNAIDS: Data 2019, Global and Regional Data, Geneva, Switzerland; 2019. p. 1-476.

7. Turkey Ministry of Health, General Directorate of Public Health, Department of Infectious Diseases. HIV-AIDS Statistics, 2019.

8. Yılmaz A, Başkan S. Evaluation of primary and high school students' knowledge about AIDS. J Curr Pediatr 2014;1:9-15.

9. Demir G, Şahin KT. [Knowledge of students of Selçuk University about sexually transmitted infections]. Düzce Üniversitesi Sağlık Bilimleri Enstitüsü Dergisi 2014;4:19-24.

10. Özdemir L, Ayvaz A, Poyraz Ö. The level of knowledge of students in Cumhuriyet University about the sexually transmitted diseases. C.Ü. Tıp Fakültesi Dergisi 2003;25:4-10.

11. Tekgül N, Saltık D, Tuncer Ö. [Importance of sexual health education for approving adolescents' responsibility about their health]. Tepecik Eğit Hast Derg. 2014;24:179-85.

12. Güçlü S, Elem E, Unutkan A. [An intervention to increase sexual health information levels of youth: peer education Project]. Eğitim ve Öğretim Araştırmaları Dergisi 2015;4:156-62.

13. Gökgöz Ş, Koçoğlu G. [The effects of trainning about smoking at adolescence period]. Firat Tip Dergisi 2009;14:33-41.

14. Gümüş İ, Kurt, M, Ermurat GD, Fayetorbay E. [Determining the level of knowledge, attitude and behavior of the students in high school in the subject of drug addiction (The Case of Erzurum)]. EKEV Akademi Dergis. 2011;15:321-34.

15. Siddiqui AF, Salim AMS. Awareness of substance use and its associated factors in young Saudi Students. J Med Allied Sci 2016;6:61-7.

16. Gotsang G, Mashalla Y, Seloilwe E. Perceptions of school going adolescents about substance abuse in Ramotswa, Botswana. Journal of Public Health and Epidemiol 2017;9:151-60.

17. Zurfi BMN, Fuad MDF, Ghazi HF, Abdalqader MA, Elnajeh M, Baobaid MF. Knowledge, attitudes and beliefs related to drugs among Pahang Matriculation students in Malaysia. International Journal of Public Health Research 2016;6:750-6.

18. Theou C, Nayak AK, Jose TT. A Study to determine the effectiveness of an awareness programme on knowledge on substance abuse and its consequences among the students of a selected pre university college of Udupi district, Karnataka. March Nitte University Journal of Health Science 2015;5:537.

19. Nwosu UM, Ezejindu CN. Knowledge and attitude on abuse of drugs among youths (15-26 years) in Umulogho Obowo, Imo State. European Journal of Pharmaceutical and Medical Research 2017;4:245-50. 
20. Elkin N. [Investigation on the knowledge of undergraduate students' about sexually diseases]. Mersin Univ Sag Bilim Derg 2015;8:1-14.

21. Amu EO, Adegun PT. Awareness and knowledge of sexually transmitted infections among secondary school adolescents in Ado Ekiti, South Western Nigeria. J Sex Transm Dis 2015;2015:260126.

22. Nwatu C, Ekenechukwu Y, Ezela Adikaibe B, Okafor C, Onwuekwe I. HIV and sexually transmitted infections knowledge and practices: a survey of female secondary school students in Enugu, South East Nigeria. JMR 2017;3:66-70.

23. Genz N, Könzgen-Meincke SM, Carret-Vidal ML, LopesCorrea AC, Neumaier-Alves C. Sexually transmitted diseases: Knowledge and sexual behavior of adolescents. Texto Contexto Enferm 2017;26:3-12.

24. Biri A, Korucuoğlu Ü, Yılmaz E, Şimşek Ç, Aksakal FN, İlhan M. Evaluation of adolescent girl's requirement of knowledge on sexuality. Turk J Obstet Gynecol 2007;4:104-7.

25. Yazganoğlu KD, Özarmağan G, Tozeren A, Özgülnar N. Knowledge, behavior and attitudes of university students toward sexually transmitted infections. Turkderm- urk Arch Dermatol Venereol 2012;46:20-5.

26. Çaltık Yılmaz A, Başkan S. Evaluation of primary and high school students' knowledge about AIDS. J Curr Pediatr 2014;1:9 15.

27. Ekşi Z,Kömürcü N. Knowledge level of university students about sexually transmitted diseases. Procedia-Social and Behavioral Sciences 2014;122:465-72.

28. Jain MA, Jain SM, Patil S, Bang A. A study on knowledge, attitude and practice of sexually transmitted diseases and HIV in adolescent population in Wardha, Maharashtra, India. Int J Contemp Pediatr 2016;3:367-72.

29. Çalışkan T, Çevik C, Ergün S. Evaluation of the knowledge the group of university students about sexually transmitted diseases. BAUN Sağ Bil Derg 2015;4:27-31.

30. Bakır N, Kızılkaya Beji N. [Evaluation of the knowledge levels of students about sexually transmitted diseases]. Düzce Üniversitesi Sağlık Bilimleri Enstitüsü Dergisi. 2015;5:10-6.

31. Malki BM. Knowledge and awareness of sexually transmitted diseases among Male University students in Taif, Saudi Arabia. Int J Med Sci Public Health 2014;3:342-8.

32. Tavoosi A, Zaferani A, Enzevaei A, Tajik P, Ahmadinezhad Z. Knowledge and attitude towards HIV/AIDS among Iranian students. BMC Public Health 2004;4:17.

33. Andrew PO, Bhuiyan A, Mawson A, Buxbaum SG, Sung JH, Shahbazi M. HIV/AIDS Knowledge of undergraduate students at a historically black college and university. Diseases 2018;6:98.

34. Tung WC, Cook DM, Lu M, Ding K. A comparison of HIV knowledge, attitudes, and sources of STI information between female and male college students in Taiwan. Health Care Women Int 2015;36:870-82.

35. Visalli G, Picerno I, Vita G, Spataro P, Bertuccio MP. Knowledge of sexually transmitted infections among younger subjects of the city of Messina (Sicily). J Prev Med Hyg 2014;55:17-22.

36. Samkange-Zeeb FN, Spallek L, Zeeb H. Awareness and knowledge of sexually transmitted diseases (STDs) among school-going adolescents in Europe: a systematic review of published literature. BMC Public Health 2011;11:727. 